\title{
Water management in the Vistula delta (Poland)
}

\author{
Piotr Jan Kowalik \\ Gdańsk University of Technology, Gabriela Narutowicza 11/12, 80-233 Gdańsk, Poland
}

\begin{abstract}
This paper presents past and recent water management in the area called the Vistula Delta Fens (Żuławy Fens). This area $(56 \times 56 \mathrm{~km})$ is located at the outlet of the Vistula River to the Baltic Sea, at the shore of the Gulf of Gdańsk. A large part of the area (30\%) is located below sea level as potentially submerged depressions. A multitude of rivers, channels, ditches and pumping stations have been constructed here over several centuries. The area is characterized by highly productive alluvial soils, surface water with a high potential for fish-farming and fishery, and attractive tourist areas at the banks of the rivers and channels. Historically, floods have occurred repeatedly as a result of: (i) - breaks in the dams along big rivers, e.g. after heavy rains and high water levels (in summer); (ii) - dam breaks caused by accumulation of ice-cakes in winter or during spring times; (iii) - dam breaks after storms on the sea with increasing sea water levels at the river outlets (mainly in winter); (iv) - overflow of water into flat land after heavy rains followed by slow drainage of water from the fields, ditches, channels and pumping stations (in summer); (v) - overflow of water into depressions and swamps below sea level after interruptions of, or decreases in, the pump operations at the pumping stations. The EU directive on flood control advises that the member countries should: (i) produce maps of the areas vulnerable to floods to facilitate communication and planning; (ii) - develop management plans for flooding events; (iii) - exchange experience and codes of good practice during flood; (iv) - facilitate a close cooperation between the scientific community and politicians in the field of flood protection; (v) - raise the level of knowledge, communication and awareness among local societies living in areas prone to flooding.
\end{abstract}

Keywords: delta of the River Vistula, depressions, floods, history, submergence

Submitted 2 October 2015, revised 19 December 2015, accepted 4 May 2016

\section{Introduction}

The Vistula Delta Fens is an area that differs from other geographical regions of Poland because of its topography, hydrology and soil types. Geologically, the Vistula delta (called here Vistula Delta Fens) is relatively young, only 6000 years old. It is a flat area, located partly below sea level, which is constantly dewatered using pumping stations (Kowalik 1980, 2001). In principle, it is a so-called internal delta formed in the area of the previous Vistula lagoon, between hills of glacial origin in the east and west, and sand-bars at the north. The latter form the border between the Baltic Sea (Gulf of Gdańsk) and the Vistula Lagoon. The border between the deposits of glacial origin and the alluvial soils lies at about $10 \mathrm{~m}$ above the sea level. This elevation forms two natural boundaries between Gdańsk and Tczew in the west, and between Malbork and Elbląg in the east. The surface area of the delta is about $56 \times 56 \mathrm{~km}$ and the Delta Fens cover about 170000 ha of this.

A large part of the delta would be permanently submerged in its natural state since there is no gravitational outflow of water. It is, however, maintained as a terrestrial ecosystem by continuous and intensive dewatering using pumping stations (Cebulak 2004a). Due to the natural ge- ology and hydrology of the area, floods can occur when water temporarily covers the soil and later drains away.

The northern part of the Vistula Delta Fens differs from the southern part. The border lies parallel to a line of latitude, passing the city of Nowy Staw in the middle of the delta. The elevation of the southern part is more than $2.5 \mathrm{~m}$ above sea level (a.s.l.) and this area is called the Higher Fens. It was never the bottom of the lagoon, and alluvial cones cover this area. The northern part, the Lower Fens, has an elevation below $2.5 \mathrm{~m}$ a.s.1., and with several depressions down to $-2.20 \mathrm{~m}$ below sea level. In the past a large part of the northern area constituted the bottom of the lagoon, and the whole area was permanently submerged until mediaeval times (Kowalik 1982).

The whole area of the Delta Fens is very flat, but some small level differences can be observed. At the border of the Fens there are some elevated outwash deposits derived by erosion from marginal upland areas (Gdańsk, Pszczółki), and some previous isles are also visible (Jegłownik, Grabina Zameczek). The total population of the area is about 200000 , and about half of them live in the suburbs of the cities (Gdańsk, Malbork, Elbląg), with the other half living in the countryside (about 200 larger villages).

In the Fens there are many different rivers. Contrary 
to the upstream part of the country to the south, where each river flows in one riverbed, the rivers in the Fens area spread and flow in different directions, forming a network of multiple riverbeds (Fig. 1).

Starting from the south we can observe the first branching of the Vistula River at Biała Góra, where one branch, called Leniwka, flows partly to the north (to Tczew and Gdańsk). A second branch, called Nogat, flows to the north-east to Malbork and Elbląg, and finally to the Vistula Lagoon. In the delta area we can see several similar branchings. At Gdańska Głowa, the Leniwka River is divided into two river-beds: the Leniwka (flowing to Gdańsk) and the Szkarpawa, flowing east to the Vistula Lagoon. In the village Rybina, Szkarpawa is further divided into two branches: the Szkarpawa and Wisła Królewiecka. At Przegalina, a part of the Vistula River flows north in the riverbed called Przekop Wisły, discharging into the Gulf of Gdańsk, but another part flows to the west as Martwa Wisła. The latter branches further into two rivers at Górki Zachodnie. One flows to Gdańsk and the outlet of the Vistula called Wisłoujście, and the other flows to the north as a river-bed called Wisła Śmiała ending in the Gulf of Gdańsk. Many branches of the rivers may be observed close to their outlets to the Vistula Lagoon, where rivers like the Nogat, Szkarpawa and Wisła Królewiecka form fens with many short and differentiated river-beds.

Formerly the Vistula delta was periodically subjected to floods. Some areas were completely submerged, whereas in others the soils were fully water-saturated but not inundated. It all depended on the topography, i.e. whether the area was located above sea level with free drainage, or

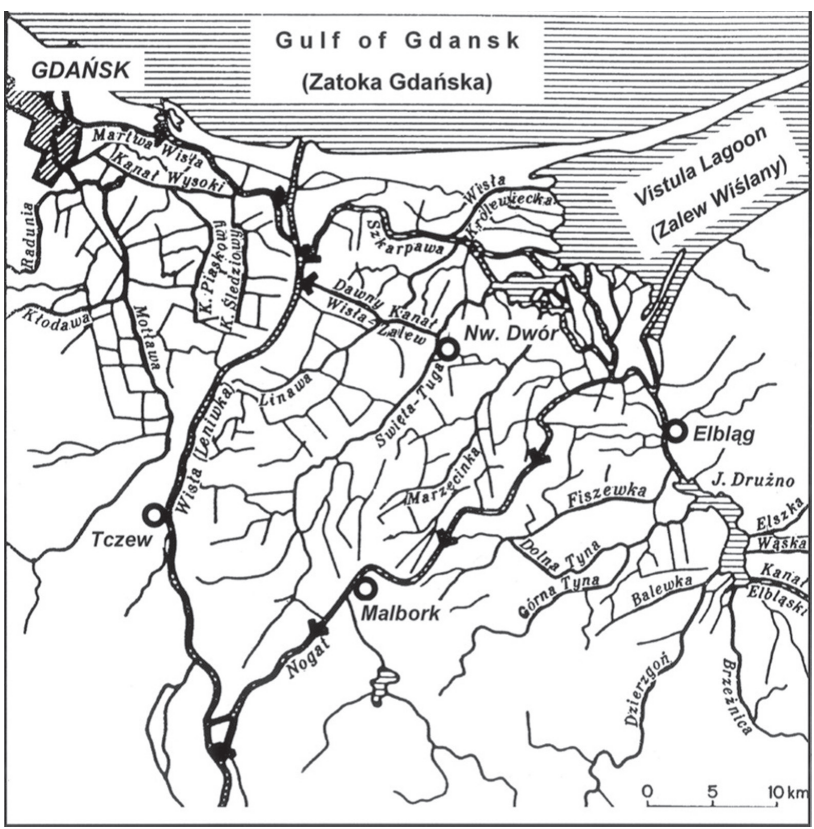

Fig. 1. River-beds in the area of the Vistula Delta Fens (Szukalski 1975) the area was located below sea level in the depressions. The latter were permanently submerged after floods, until man-made dewatering started. Hence a very particular situation can be observed in the depressions. Some people say that human activities in the depressions are against nature, as the natural status of those areas would be their permanent submergence (Cebulak 2004b). When the dams along the rivers or channels break, the depressions become totally submerged, and revert to their former status as water bodies.

Pumping stations in the polders maintain water levels inside the polders at $3 \mathrm{~m}$ below the mean sea level, or even lower. The area of the depressions is not visible in the landscape, because the soil surface is very flat everywhere.

Depressions are, however, delineated on maps as they are marked with a different colour to the areas above sea level (Bertram 1907; Cebulak 2004b) (Fig. 2).

Fifty polders with 105 pumping stations cover about $70 \%$ of the Fens' total area of 170,000 ha, and polders with gravitational water outflow cover the rest. Depressions below sea level make up $27 \%$ of the Fens area, and they are located mainly close to Gdańsk, Elbląg and Lake Drużno (Cebulak 2006a). The lowest level in the vicinity of Elbląg is $-2.20 \mathrm{~m}$. In the vicinity of Gdańsk, the lowest depression is $1.60 \mathrm{~m}$ below sea level and it is located in the polder Olszynka. The tops of the dams in this polder reach about 2.20-2.50 m above sea level (Cebulak 2004c). Close to Gdańsk, there are several polders below sea level, e.g. Orunia, Olszynka, Rudniki, Sobieszewo, Przejazdowo, Wiślinka, Rokietnica, Niegowo. Most recently they were all flooded during the year 2001 .

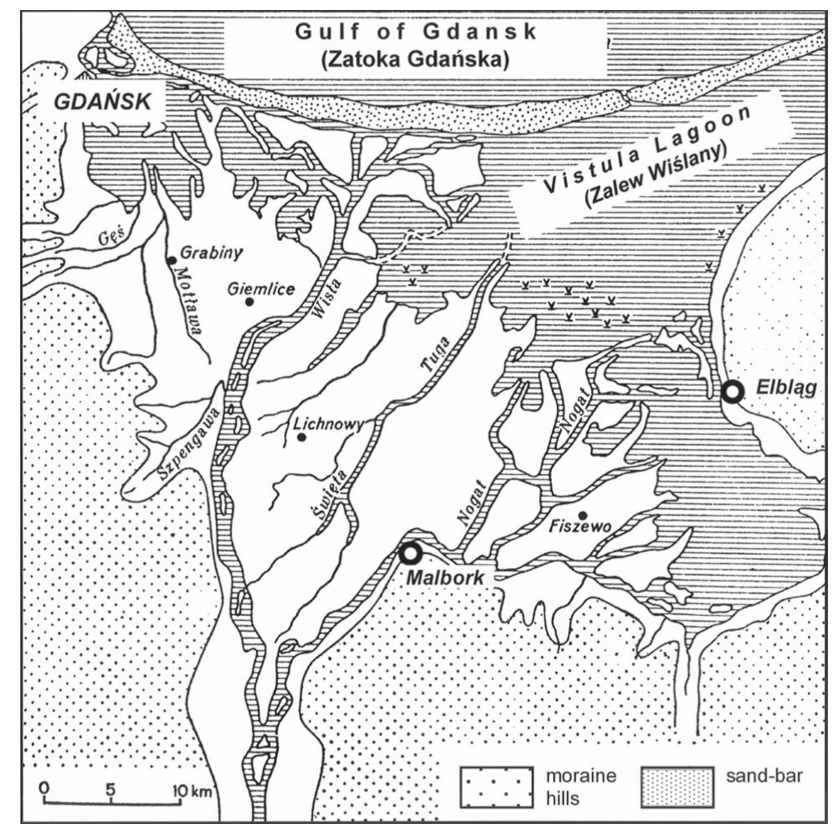

Fig. 2. The Vistula Delta Fens in the past: year 1300 (Bertram 1907); white areas are alluvial soils, hatched areas are waters 


\section{History of floods before the year 1895}

The whole area is very prone to flooding. One reason is the risk of breaks of dams along the Vistula river-bed, some of which could be caused by the accumulation of icecakes. Other risk factors are local heavy rains in the area, or floods generated by storms with high sea water levels, mainly in the Vistula Lagoon (Majewski 1980, 2013).

In the upstream part of the delta there are three villages situated in a small triangle: Piekło, Biała Góra and Żydzia Góra. This triangle has the shape of the Greek letter "delta". This was the place chosen for a regulatory construction called "Szpica Mątowska", built in the riverbed of the Vistula to divert the flow in two directions: to Gdańsk or to Elbląg. During the XVII century, the city of Elbląg demanded that more water be diverted via the Nogat, and this caused a local war over the water. The consequence of this was a regulation issued by King Sigismund III Wasa. In 1612, a big pile (sharply pointed) was built in the river, to divert $2 / 3$ of the Vistula water to Leniwka, flowing to Gdańsk, and 1/3 to the Nogat, flowing to Elbląg (Cebulak 2005a). This was only a temporary solution to the controversy over the Vistula water.

In 1657, the Swedish army occupying Poland decided to destroy the dam in Kiezmark, close to Gdańsk, and the entire delta was flooded for several years (Cebulak 2004b). In Gdańsk, floods were used as a protective measure during wars, against the Swedish (in 1655-1660), the Russian (in 1734), and the Prussian armies (in 1813) (Cebulak 2004c).

The most critical point in the delta area is Kiezmark, where there is an accumulation of ice-cakes every winter, which causes a high risk of dam breaks. Such a catastrophe occurred in 1829 (Makowski 1994), when the whole city of Gdańsk was flooded with water up to a level above the ground floors of the city houses. A similar accumulation of ice-cakes occurred in 1840 in Górki Zachodnie, when a new river, the Wisła Śmiała, was formed. In 1956, there was an ice cake accumulation in Przekop Wisły, and in 1971 in Świbno (Majewski 1980), but this only caused flooding of the sandbar area, not the Fens.

In the winter of 1888 , there was a large accumulation of ice in the Nogat River. The dams were destroyed, and all the depressions around Lake Drużno were submerged for several years (Cebulak 2006b).

In Trutnowy, there is a watermark on the wall of one of the churches to commemorate the maximum water level of the flood in 1829. A similar watermark can be seen on the wall of the Central Maritime Museum building in the city of Gdańsk.

\section{Excavation in the year 1895}

The excavation of a new river-bed for the Vistula River between Przegalina and Świbno (Przekop Wisły) is considered to be the biggest investment for flood control in the Vistula delta. This excavation was done in 1895 and formed a new channel across the sand-bar to allow the Vistula River to flow directly to the Gulf of Gdańsk in Świbno (Cebulak 2005b).

The purpose of this investment was to protect the city of Gdańsk from flooding, and also to protect the whole area of the Vistula delta. As a result of this channel's construction, the length of Vistula River was shortened by about $14 \mathrm{~km}$.

The flow of the Vistula River was regulated into a single river-bed, about $8 \mathrm{~m}$ above sea level, with high dams on both sides of the river. As a result, large amounts of water during high flow periods, and large amounts of icecakes, can flow freely to the Gulf of Gdańsk. All possible water leakage was blocked, Nogat, Szkarpawa and Martwa Wisła rivers were isolated from the main Vistula River, and the hydraulics and hydrology of the river system have been dramatically changed (Cebulak 2005b).

The investment started in June 1891 under relatively favorable conditions, as at the same time the excavation of the Kiel Channel had just ended (joining the Baltic Sea with the North Sea) and all the equipment was transported to Świbno. Mechanical shovels and excavators were used to dig the new channel in dry conditions. A $7 \mathrm{~km}$ long and 250-400 m wide channel was dug in the alluvial deposits of the delta. Across the sand-bar, it was merely a ditch 1.4 $\mathrm{km}$ long and several meters wide. After allowing the Vistula River water into the channel, the new river-bed was created by the force of the river flow (Cebulak 2005b). The Vistula River (here called Leniwka) was linked with the Gulf of Gdańsk on the $31^{\text {st }}$ of March, 1895 (at 15:45).

The flow of the Vistula has brought several million tons of soil into the Gulf of Gdańsk, creating a new alluvial cone, the so-called outside delta. The material originated from the sand-bar, the eroded river-bed and the suspended solids carried by the river water (Cebulak 2005b). This new outside delta is a popular place for birds and seals that live in the area.

After the completion of the new channel, investment in the River Nogat followed. This river was separated from the Vistula, and three cascades were constructed. During 1915, the Nogat River was, in principle, entirely separated from the Vistula River. It is a commonly held opinion that after 1915 the formation of the internal delta in the Vistula Lagoon stopped, and the formation of the new outside delta, in the place called Świbno, was initiated (Cebulak 
2005a). At the same time, the reconstruction of the polders in the Vistula Fens started, and is still on-going (Cebulak 2005a)

\section{The flood in 1945 (during World War II)}

The history of the Vistula Fens is a history of constant threat from floods, both from the sea and from the uplands. Water may flood both the areas with gravitational drainage and the depression areas in the polders. Such a flood occurred during 1945, when the German Army defended this area against attacks by the Russian Army. In March 27, 1945, the German Army blew up the Vistula River dams and the area was flooded. At the same time, the pumping stations were destroyed to stop possible dewatering. The biggest pumping station, Chłodniewo, was seriously damaged by bombardment from the warship, "Lützow", positioned in the Gulf of Gdańsk. The German Army also destroyed the infrastructure of many polders. The damage resulted in a flood that submerged an area of 45,000 ha. All the depressions of the Fens remained submerged for more than 4 years. This extensive submergence had an impact on more than half of the Fens' surface area, and was one of the reasons for the massive re-location of the population that used to live in the area. It was mostly people's own decision to move, but after 1945 the rest of the original inhabitants were removed to Germany. The submerged area was destroyed and totally depopulated. Dewatering of the area started in 1946 and continued till the end of 1949 (Cebulak 2006a).

Flood control relies on a system of dams along the rivers and channels, polders, pumping stations and gates. There are 5 operational water gates, which are open under normal conditions, but close automatically when the sea water level rises. This protects the area from flooding caused by storms on the sea. The outlets of the rivers are open and water may freely flow from the land to the sea, but the flow of water from the sea to the rivers is prevented by those special water gates (Cebulak 2004c). This system was invented before World War II, but it was modernized recently.

\section{The special character of the polders}

There are about 50 polders in the Vistula Delta Fens, and all of them are inhabited by people. A polder is defined as an area that is surrounded by a continuous dam, and dewatered by a pumping station (Kowalik 2001). Dams are necessary to prevent the polder area against floods and submergence. The water level outside the polder is higher than the ground level in the polder. Every polder has its own network of ditches and channels. Hence, a polder is a small catchment and water is drained by a pumping station rather than by gravity. All drains, ditches and channels within the polder are isolated from the surrounding water by dams, and the water level is controlled all the time. In the case of a flood, the whole polder is submerged and becomes a large water reservoir (Kowalik 1988). Conditions for habitation in a polder area are dependent on the flood protection system, energy supply for the pumping stations, and the highly organised life-style of the local community (Cebulak 1977).

In polder areas, roads and houses have typically been constructed on heaps (banks) of soil. In the case of a flood, all roads and houses would be located above the new water level. Those embankments under roads are still present today. The small soil heaps, on which houses were constructed, are called "tierp". These heaps were small islands, and there was limited space on such heaps available for constructing houses. Hence, buildings for humans, for animals, and for storage were located under the same roof, and the shape of the farm was like "U", "L" or "I" letters. There were never any cellars and the floors were never made out of wood; only ceramic was used. This type of house is not found in the rest of Poland, but is typical for the Vistula delta. The way of joining the house, the cowshed and the granary under a common roof makes them resemble traditional Dutch farms.

When floods occurred in the polder, it was necessary to escape from the area, but after dewatering it was time to come back and reconstruct the farms (Cebulak 2004a). In this area, polders were first constructed in the XIV century, but massive immigration from the Netherlands started during the XVI and XVII century. Later on, about 1/6 of the total population originated from the Netherlands (but about half of the area was owned by the Dutch immigrants). The first investment was to construct continuous dams around wetlands and lakes. Then the water was pumped away and the new polder became dry and possible to cultivate. All depressions were converted to polders, and a large part of the previous Vistula Lagoon was transformed from water bodies to land. During the XIX century, all the wetlands and lakes were dewatered and the process of polder construction was accomplished. The last polder was constructed in 1942 in Marzęcino, but this was quite a small area (Cebulak 2004b).

In the Netherlands, the lowest point in the depressions is at $-6.70 \mathrm{~m}$ below sea level. In the delta of Rodan in France, the lowest point is at $-2.00 \mathrm{~m}$, and in the Mississippi delta, close to New Orleans (U.S.A), the lowest point is at $-3.00 \mathrm{~m}$. In Poland, the lowest point is in the Vistula delta in Wikrowo at $-2.20 \mathrm{~m}$ (Cebulak 2005c). The extent 


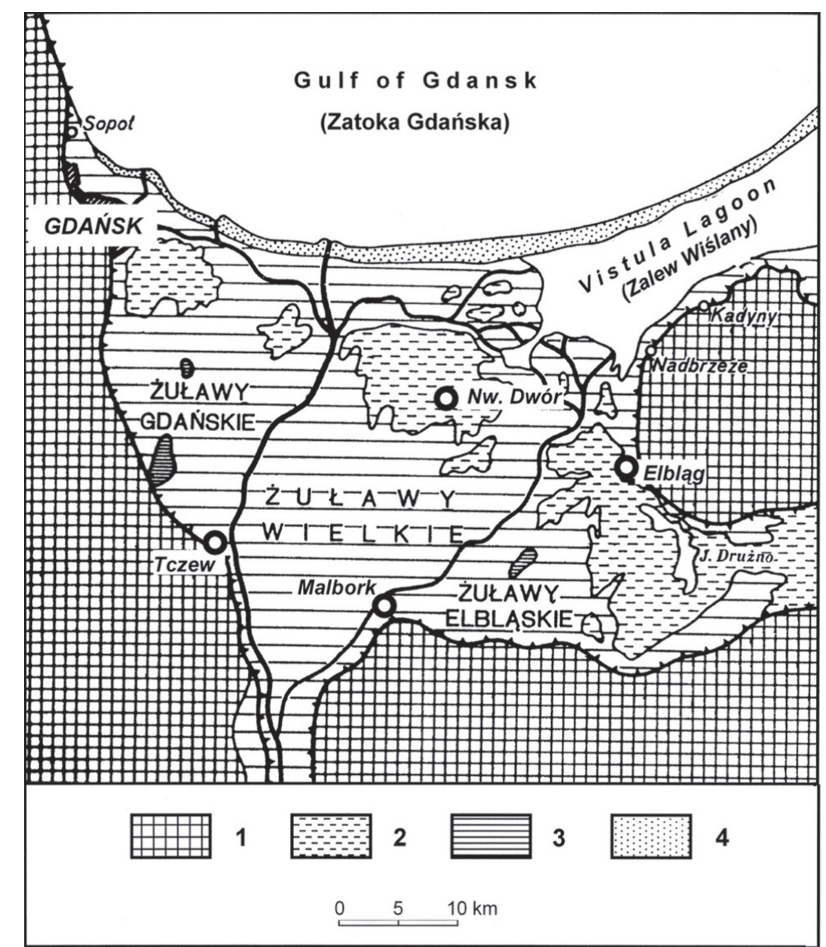

Fig. 3. Geomorphology of the Vistula Delta Fens: 1 - moraine hills; 2 - depressions in the area of delta; 3 - Pleistocene islands; 4 - sand-bar and beaches at the maritime coast (Szukalski 1975)

of the depressions in the Vistula delta is shown in Fig. 3.

The creation of a polder is an activity that changes a previous aquatic ecosystem into a terrestrial one. The former lakes or wetlands were previously covered with typical wetland vegetation, like marshy willows, reeds and alder swamps. Very often the name "lake" was not very appropriate to describe those areas (Cebulak 2006b).

Pumping stations are necessary for two reasons. Firstly, pumping is essential to create a terrestrial area by dewatering. The second reason is to regulate the level of water in the open ditches and in the soil, according to the particular strategy adopted for land improvement (Cebulak 2004a; Kowalik 1988, 2001, 2007).

Today, the depressions in the delta can be treated in two ways. The first is to allow water back into the depressions and form lakes on the previous land areas. This is called renaturalisation. The other strategy is to bring new soil and to build an embankment above sea level. Such a strategy was chosen when the oil refinery near Gdańsk was constructed. The previous depression was filled with gravel and sand, to raise the ground level, and the industrial installations were constructed above sea level (Cebulak 2006a).

\section{Specific ploughing practices in polders}

Fields and farms in the polders are separated from each other by ditches or channels, which are temporarily or permanently filled with water, just as in the polders of the Netherlands. All the fields are regular rectangles or squares with a breadth of 30,45 or $60 \mathrm{~m}$.

In the Vistula Delta Fens the fields are very flat. Open ditches provide surface drainage, and as a result of regular ditch cleaning there is usually a $10-20 \mathrm{~cm}$ high berm along the edge of the ditch. Openings of the berms are necessary to prevent prolonged surface ponding after heavy rains, which can result in anaerobic conditions in the topsoil layer, and poor workability of the soil. A particular ploughing system is recommended in order to create a new surface profile of the fields that promotes surface run-off and surface drainage. It is similar to, but not exactly the same as, the traditional "ridge and furrow" system used on heavy soils. The field should have a long rectangular shape, and instead of a ridge of land left unploughed, called a balk (or a baulk), there is a ditch. In the middle of the field along the symmetry axis, a ridge (a narrow raised strip on ploughed land) should be made from the plough slices (a thin flat piece cut from the soil body). All the plough slices should be turned after years in such a way that a ridge is formed in the middle, and a slope is created on the field (about 1\%). The last furrow formed by the plough should be at the ditch side, eliminating the danger of mud "lips" on the soil surface. The ploughing (tillage) should always start from the middle of the field, and the furrows should always be turned to the middle and never be ploughed-out. The result is that the surface of the field will gradually be transferred from a flat field to a roofshaped one. The difference with a "ridge and furrow" ploughing practice is that instead of a furrow, a new side of the ditch is created and the ridge will become higher and higher, up to $1 \mathrm{~m}$ above the original level of the soil (Kowalik 2006).

This system was implemented long ago in Germany (Reich 1905) and in the Netherlands (De Bakker, Marsman 1981). Such fields were quite common in the Netherlands before the practice of tile drainage. Clay-ware pipes for subsurface drainage are not allowed in many Histosols and Inceptisols, because of their high content of mobile iron. In such soils, open ditches are still needed for surface drainage.

\section{Conclusions}

The most important recommendations for human activity on the Fens are:

- houses and roads must be located in higher positions, mainly on constructed banks;

- it is not allowed to construct cellars in buildings; houses, cow-barns and granaries must be under a common 
roof; it is not allowed to construct wooden floors, only ceramic based ones;

- there must be ditches along the field edges, which should be regularly cleaned and, in advance, pumping stations on the polders and bigger reservoirs should be constructed to collect the water from the ditches and channels;

- the surface of the fields should have a roof-like slope with a higher centre and lower margins;

- dams must be high, non-permeable and stabile;

- ice-jams on the Vistula river should be prevented (mainly close to Kiezmark), and it is necessary to have several icebreakers ready for work at the end of the winter;

- the bigger channels must have water-gates to prevent the inflow of the sea water to the Fens area.

The EU directive on flood control advises that member countries: (i) - produce maps of the areas vulnerable to floods to facilitate communication and planning; (ii) - develop management plans for flooding events; (iii) exchange experiences and codes of good practice during floods; (iv) - facilitate close cooperation between the scientific community and politicians in the field of flood protection; (v) - raise the level of knowledge, communication and awareness among local societies living in areas prone to flooding.

Bibliography

Bertram H., 1907, Die Entwicklung des Deich und Enwässerungswesens, Druck der Danziger Allgemainen Zeitung, Danzig, 194 pp.

Cebulak K., 1977, Vistula Delta Fens as an example of polder integration in a developmental processes of land reclamation (in Polish), Ph. D. Thesis, Gdańsk University of Technology

Cebulak K., 2004a, Chłodniewo - a polder and a pumping station in the Vistula Delta (in Polish), Jantarowe Szlaki, 2 (272), 24-27

Cebulak K., 2004b, Pumping station Osłonka and Marzęcin depression in the Vistula Delta (in Polish), Jantarowe Szlaki, 3 (273), 5-9,

Cebulak K., 2004c, About the struggle against storms in the Vistula Delta Fens (in Polish), Jantarowe Szlaki, 4 (274), 8-12

Cebulak K., 2005a, Where the Vistula River delta begins (in Polish), Jantarowe Szlaki, 1 (275), 1-4
Cebulak K., 2005b, Here the Vistula River ends (in Polish), Jantarowe Szlaki, 2 (276), 3-7

Cebulak K., 2005c, On the lowermost site in Poland (in Polish), Jantarowe Szlaki, 4 (278), 18-21

Cebulak K., 2006a, On polder depressions in the Vistula Delta (in Polish), Jantarowe Szlaki, 1 (279), 7-11

Cebulak K., 2006b, On polder depressions in the Vistula Delta Fens around the Lake Drużno (in Polish), Jantarowe Szlaki, 3 (281), 9-14

De Bakker H., Marsman B.A., 1981, Cresty fields: fields with an elevated centre and lower margins, Boor \& Spade, 20, 9-38

Kowalik P., 1980, Water management in the Vistula Delta Fens (in Polish), [in:] Peribalticum, Problemy Badawcze Obszaru Bałtyckiego, B. Rosa (ed.), Wydawnictwo GTN, Gdańsk, 125-130

Kowalik P., 1982, Polders of the Vistula River. In: Polders of the World, [in:] Proceedings of the International Symposium, Volume I, Lelystad, Netherlands, ILRI, Wageningen, 58-66

Kowalik P., 1988, Water management and drainage design of a selected polder, Agricultural Water Management, 14, 103-112

Kowalik P., 2001, Polder water management in the Vistula Delta Fens (in Polish), Monografia KGW PAN, Warszawa, 154 pp.

Kowalik P., 2006, Drainage and capillary rise component in water balance of alluvial soils, Agricultural Water Management, $86,206-211$

Kowalik P., 2007, Water and agriculture - a general overview, Tidskrift, The Royal Swedish Academy of Agriculture and Forestry, 146 (1), 7-10

Majewski A., 1980, Flood threat and water salinity in the Vistula Delta Fens (in Polish), [in:] Wybrane problemy rolnictwa, gospodarki wodnej i zagospodarowania przestrzennego Żuław delty Wisły - gospodarka wodna, Rada Koordynacyjna PAN w Gdańsku, Gdańsk, 43-50

Majewski W., 2013, Sustainable development of the Lower Vistula, Meteorology Hydrology and Water Management, 1 (1), 33-37

Makowski J., 1994, The utmost flood catastrophe in the history of Gdańsk and the probability of its re-occurrence (in Polish), Hydrotechnika, 18, 1-48

Reich A., 1905, Das Meliorationwesen, E. Engelmann, Leipzig, $107 \mathrm{pp}$.

Szukalski J., 1975, The Vistula Delta Fens (in Polish), Wydawnictwa Szkolne i Pedagogiczne, Warszawa, 152 pp. 